\title{
Subaltern Voice in the Novel of Anita Nair's Lessons in Forgetting: A Female Perspective
}

\section{Sugandhyasree Bhattacharjee}

Ph.D Research Scholar, Department of English, Mahapurusha Srimanta Sankaradeva Viswavidyalaya, Assam, India

\begin{abstract}
Anita Nair is a well known novelist, dramatist, essayist in the postmodern writing s.She attempts to raisr the voice of the subaltern in her novels and set examples for the society who thinks women as an inferior human being or a women who has identity only through her husband or family.This paper is a study of Anita Nair's Lessons in Forgetting in the light of subaltern voice of the female protagonist 'Meera'in the novel. The crux of the play is that women who is taken to be as a part of physical and mental abuse should protest back to prove her potentiality in the society. As the play opens, the audience witnesses the truth that women can be self dependent on herself if she decides to be. She needs no one to hold her to run her future. She is not born to treat her for domestic abuses.

Keywords-Anita Nair, Women Dramatist, Subaltern

Voice, Domestic Abuse.
\end{abstract}

Anita Nair is popularly known among the women dramatist in the post modern writings.Although she doesn't want to categorize herself as a feminist writer still she writes for women to raise their voice in the society.She is one of the finest figure who tries to show the violences faced by women and fight back against them and how to set example for themselves and the patrairchal society.In her every novel she makes women to be independent in their life.

In the play, the female protagonists, Meera belongs to a upper middle class family and inspite of being born to a upper class she has to go through the cyclone in her life as she is born as a girl. In the beginning of the novel, Meera leads a beautiful life in The Lilac's house till a major change came in her life.The play revolves around The Lilac's house where Meera's major change takes place. She gets married to Giri who came as a model coordinator to assist shooting for a film and falls for Meera seeing her beauty.He also gets greed for the Lilac's house thinking that to be owned by Meera and decides to marry Meera. Giri gets wrong to think Meera to be the owner but in reality that house is on leash to them. Giri thinks that if he marries Meera he can live a lavish life and also thinks to sale The Lilac's house.Meera is portrayed as a women who submits herself to her husband after marriage and has vanished all her dreams after marriage and gets in to take care of her husband and her husband. She forgets herself and her identity while taking care of her husband.Giri,the husband is portrayed as a man who does not respects his wife and also has a lust and greed only for her materialistic needs. He does not even love his wife and has no attachment towards her. Meera doesnot even raise her voice when she finds her husband to be wrong and listens to his every word like a typical woman. The portrayal of the women figure depicts the true life of a woman in indian society. Meera was entirely dependent on Giri till the time she didnot realize herself. She was not able to face the harsh reality of being thrown away by her husband from his life and his betrayal after she rejected to sale The Lilac's house.

She wants to pull the quilt over her head and burrow herself in a warm, dark placr where nothing will change and all is safe and restful(99).

Meera, a traditional woman didnot realize her potentialities untill she was dependent.She suddenly started to realize her change after being she was left alone by her husband to take care of the family and take the household duties upon her. Her husband was in the wrong perception thinking her to be dependent on him and he will be called back to her life.So, he tried to make her fear by leaving her alone when she said no to his decision and make her bound to listen to him. But, Meera turns opposite to his utter surprise. She learnt how to live the life without depending on her husband.

Being a postgraduate in English she could easily pave her path for a job. She becomes a changed woman. Her mother and grandmother notices this:

And a measuring spoon that didn't brim anymore. But they said nothing.The stern cast of her face alarmed them more than Meera realized. (84).

Meera had completely bought a new change over herself. She had a haircut and started to go for parties and enjoy her life to the fullest. She enjoys parties without any companion. When her friend Vinnie,asks her if she needs a companion, she replies

No there isn't anyone I want to bring with me(183). 
Meera now turns to enjoy her life.She even finds a job for herself as a research assistant and becomes economically independent. She realize her identity which was lost after her marriage.

Anita Nair in her novel through the protagonist Meera sets a new example for the woman society who completely forgets her identity in taking care of her husband and her family. She turns completely dependent on her husband and submits herself to listen to her husband. Anita Nair shows the dark reality of the society where many women can make themselves independent but fails in making it as they remain dependent. She raises the voices of the subalterns in all her novels and asks women to be strong and realize themselves.

\section{REFERENCES}

Nair, Anita. Lessons in Forgetting.New Delhi: Penguin Books, 1997.Print.

Patil, Dnyandeo Poonam,'Female protagonists in the novels of Anita Nair : A Feminist perspective',Bharati Vidyapeeth Deemed University,Pune,August 2017. 